\title{
PENGEMBALIAN PENDAHULUAN KELEBIHAN PAJAK SEBAGAI ALTERNATIF MEMBANTU CASHFLOW PT CONTINENTAL PANJIPRATAMA PADA MASA PANDEMI COVID-19
}

\author{
Andreas Bambang Daryatno ${ }^{1}$ \\ ${ }^{1}$ Program Studi S1 Akuntansi Universitas Tarumanagara,Jakarta \\ Email:andreasb@fe.untar.ac.id
}

\begin{abstract}
Tax refunds aim to return tax overpayments in accordance with applicable regulations, where the excess tax is the right of the taxpayer. The government has an obligation to return the excess tax that is not owed from the taxpayer. There are two methods of restitution, namely restitution by conducting a tax audit first and restitution of preliminary refunds of overpayment of taxes only by doing research. Special preliminary refunds are given to certain taxpayers who meet the stipulated criteria or obedient taxpayers who have fulfilled their tax obligations well and have low risk. During this COVID-19 pandemic, taxpayers are trying to get a preliminary restitution facility because in addition to just doing research, the disbursement of excess tax payments by the government is also accelerated, even the government through the Job Creation Law has issued relaxations related to restitution. The accelerated disbursement of excess tax payments greatly helps the company's cashflow so that it can survive the drought of financial liquidity as a result of the impact of the COVID-19 pandemic. The method used is to provide counseling and assistance in meeting the requirements set by the government, so that the application for a preliminary refund of the overpayment of taxes can be received and processed quickly in accordance with applicable regulations. To expedite and speed up the preliminary testing process in increasing the company's cashflow, I, as a lecturer at Tarumanagara University, Faculty of Economics, Accounting Department, carried out counseling and assistance in the accounting and tax department with the title "Preliminary Refund of Excess Taxes as an Alternative to Help PT Continental Panjipratama Cashflow During the Covid-19 Pandemic. "'
\end{abstract}

Keywords: restitution, preliminary refund, tax overpayment, cashflow

\begin{abstract}
ABSTRAK
Restitusi pajak bertujuan untuk mengembalikan kelebihan pembayaran pajak, sesuai dengan peraturan yang berlaku, dimana kelebihan pajak tersebut merupakan hak daei wajib pajak. Pemerintah mempunyai kewajiban untuk mengembalikan kelebihan pajak yang tidak terutang dari wajib pajak. ada dua metode restitusi yaitu restitusi dengan dilakukan pemeriksaan pajak terlebih dahulu dan restitusi pengembalian pendahuluan kelebihan pembayaran pajak hanya dengan dilakukan penelitian saja. Restitusi pendahuluan khusus diberikan kepada wajib pajak tertentu, yang memenuhi kreteria yang ditetapkan atau wajib pajak patuh yang telah memenuhi kewajiban perpajakan secara baik dan memiliki resiko yang rendah. Pada masa pandemic covid-19 ini, para wajib pajak berusaha mendapatkan fasilitas restitusi pendahuluan karena selain hanya dilakukan penelitian saja, pencairan kelebihan pembayaran pajak oleh pemerintah juga dipercepat bahkan pemerintah melalui Undang-Undang Cipta Kerja mengeluarkan relaksasi berkaitan restitusi. Pencairan kelebihan pembayaran pajak dipercepat sangat membantu cashflow perusahaan supaya dapat bertahan menghadapi kekeringan likuiditas keuangan sebagai dampak dari hantaman pandemi covid-19. Metode yang dipakai dengan memberikan penyuluhan dan pendampingan dalam memenuhi persyaratan yang telah ditetapkan oleh pemerintah, supaya permohonan pengembalian pendahuluan kelebihan pembayaran pajak dapat diterima dan diproses secara cepat sesuai dengan ketentuan yang berlaku. Untuk memperlancar dan mempercepat proses testitusi pendahuan dalam meningkatkan cashflow perusahaan maka saya selaku dosen Universitas Tarumanagara Fakultas Ekonomi Jurusan Akuntansi melaksanakan penyuluhan dan pendampingan di bagian akuntansi dan pajak dengan judul "Pengembalian Pendahuluan Kelebihan Pajak Sebagai Alternatif Membantu Cashflow PT Continental Panjipratama Pada Masa Pandemi Covid-19"
\end{abstract}

Kata kunci: restitusi, pengembalian pendahuluan, kelebihan pajak, cashflow

\section{PENDAHULUAN}

Pajak adalah sumber penerimaan negara untuk membiayai seluruh pengeluaran termasuk pengeluaran untuk pembangunan dan pengeluaran dalam meningkatkan kesejahteraan seluruh rakyat Indonesia. menurut Undang-undang Nomor 16 Tahun 2009 pajak adalah "kontribusi 
wajib kepada negara yang terutang oleh orang pribadi atau badan yang bersifat memaksa berdasarkan Undang Undang, dengan tidak mendapat timbal balik secara langsung dan digunakan untuk keperluan negara bagi sebesar-besarnya kemakmuran rakyat." Pengertian lain, pajak adalah iuran yang dapat dipaksakan kepada negara, berdasarkan peraturan-peraturan terutang dari wajib pajak dan wajib dibayarkan dengan tidak mendapat prestasi secara langsung, digunakan untuk membiayai pengeluaran-pengeluaran umum. Jadi disini sangat dibutuhkan kesadaran dari seluruh rakyat Indonesia untuk membayar pajak sesuai dengan Undang-Undang yang ditetapkan oleh pemerintah. Wjib pajak diwajibkan membayar pajak yang diatur oleh pemerintah melalui Undang-Undang yang didalamnya terdapat hak dari wajib pajak.

Restitusi adalah hak yang diberikan pemerintah kepada wajib pajak, sedangkan restitusi pajak adalah pengembalian kelebihan pembayaran pajak yang tidak terutang dari wajib pajak. Adapun tujuan dari restitusi pajak yaitu melindungi hak wajib pajak dengan memberikan kepercayaan. Sedangkan menurut Ketentuan Umum dan Tata Cara Perpajakan (UU KUP) adalah permohonan pengembalian kelebihan pembayaran pajak yang dilakukan oleh Wajib Pajak kepada negara dimana pajak itu adalah hak dari wajib pajak. Maksudnya pajak yang telah dibayarkan oleh wajib pajak, dibayarkan Kembali oleh negara kepada wajib pajak.( https://klikpajak.id/blog/). Ada dua kondisi yang dapat dilakukan untuk mendapatkan Pengembalian kelebihan pembayaran pajak (https://flazztax.com/2019/11/27/sudahkah) yaitu:

1. Suatu keadaan dimana Wajib Pajak membayar pajak padahal seharusnya tidak terutang pajak.

2. Suatu keadaan dimana Wajib Pajak membayar pajak lebih besar dari yang semestinya. Pada pasal 17 ayat 1 UU Nomor 28 Tahun 2007 (KUP) disebutkan, Direktorat Jenderal Pajak setelah melakukan pemeriksaan, akan menerbitkan Surat Ketetapan Pajak Lebih Bayar (SKPLB) hal ini terjadi jika jumlah jumlah pajak yang dibayar lebih besar (kredit pajak) daripada jumlah pajak yang terutang artinya jika terjadi kelebihan pembayaran PPh, PPN, dan /atau PPnBM dapat dikembalikan (restitusi). Meskipun Pengembalian pembayaran pajak (restitusi) yang dikembalikan kepada wajib pajak secara langsung akan mengurangi jumlah penerimaan pajak (Erly Suandy; 2011:163). Konsisten dengan hasil penelitian Innaka Silvy Adi Windha (2021) bahwa restitusi PPN mempunyai pengaruh pada penerimaan PPN. Penerimaan PPN dipengaruhi Jumlah Pengusaha Kena Pajak. Sosialisasi perpajakan memperkuat pengaruh restitusi PPN terhadap penerimaan PPN dan jumlah PKP terhadap penerimaan PPN. Tetapi hasil penelitian Sarah Usman (2017) tidak konsisten karena secara regresi hanya 23\% yang dapat ditafsirkan terhadap variabel bebas dan $77 \%$ lainnya dipengaruhi oleh faktor-faktor lain diluar variabel restitusi pajak. Nilai korelasi bersifat lemah (significant 0,336) dan variabel restitusi tidak berpengaruh terhadap penerimaan pajak. Secara prinsip pemerintah sudah mengatur berkaitan dengan adanya restitusi pajak akibat adanya kelebihan pembayaran pajak dan Hasil penelitian Bryan,Treesje, Rudy (2017) masyarakat harus tahu bahwa meskipun uang telah masuk ke kas negara jika terbukti ada pembayaran lebih maka kas negara juga bersedia untuk mengembalikan atau menggantinya jenis pajak lainnya.

Dalam proses restitusi, menurut peraturan Undang-Undang yang berlaku memungkinkan untuk dilakukan pengembalian pendahuluan tanpa dilakukan pemeriksaan pajak, melainkan melalui penelitian saja.berdasarkan pasal 17C atau pasal 17D Undang-Undang KUP, atau Pasal 9 ayat (4c) Undang-Undang PPN wajib pajak dimungkinkan untuk mendapatan restitusi lebih awal dibandingkan dengan restitusi normal. Hal ini menyebabkan prosesnya relatif lebih cepat yaitu melalui proses penelitian ketimbang restitusi pada umumnya, harus melalui proses pemeriksaan dengan waktu bisa mencapai 12 bulan. Apalagi pemerintah melalui pasal 113 angka 8 UndangUndang Nomor 11 Tahun 2020 tentang Cipta Kerja ("UU Cipta Kerja") memberikan relaksasi pajak dengan mengubah pasal 17B ayat 1 Undang-Undang Nomor 6 Tahun 1983 (KUP). 778 
Melalui kebijakan relaksasi pajak tersebut, waktu pembayaran pajak diperpanjang paling lama 6 bulan melalui penerbitan surat ketetapan pajak berkaitan dengan permohonan pengembalian kelebihan pajak. Bahkan dalam proses restitusi pendahuluan, waktunya dipercepat mencapai 1- 3 bulan saja. Hal ini membuat banyak perusahaan pada masa pandemi, berusahan untuk mendapatkan kemudahan restitusi tersebut (https://news.ddtc.co.id/). Khusus untuk proses permohonan restitusi pendahuluan dilakukan melalui penelitian dan verifikasi untuk memastikan bahwa pajak lebih bayar tersebut benar-benar tidak terutang dan merupakan hak dari wajib pajak.tetapi jika ternyata Wajib Pajak mempunyai utang pajak, restitusi tersebut langsung diperhitungkan untuk melunasi terlebih dahulu utang pajak tersebut.

Menurut PMK 39/Pmk.03/2018 pasal 3 untuk permohonan pengembalian Pendahuluan harus memenuhi Kriteria Tertentu yaitu::

1. Sesuai pasal 2 huruf a wajib Pajak Kriteria Tertentu dapat diberikan Pengembalian Pendahuluan atas kelebihan pembayaran baik itu Pajak Penghasilan maupun Pajak Pertambahan Nilai.

2. Sesuai ayat 1 yang ditetapkan oleh Direktur Jenderal Pajak maka Wajib Pajak Kriteria Tertentu harus memenuhi syarat :

a. Dalam penyampaian SPT selalu tepat waktu.

b. Semua jenis pajak, wajib pajak tidak ada tunggakan,. Kecuali yang sudah mendapat ijin untuk mengangsur atau menunda pajak yang harus dibayarnya.

c. Laporan keuangan wajib pajak diaudit oleh KAP selama 3 (tiga) tahun berturut-turut dengan pendapat wajar tanpa pengecualian

d. Selama 5 tahun terakhir, wajib pajak tidak pernah melakukan perbuatan atau Tindakan pidana di bidang perpajakan atau putusan pengadilan yang telah mempunyai kekuatan hukum tetap

3. SPT disampaikan tepat waktu sesuai ayat 2 huruf a yaitu:

a. Dalam 3 (tiga) tahun berturut-turut menyampaikan SPT Tahunan tepat waktu.

b. SPT Masa atas Masa Pajak Januari sampai dengan November Wajib Pajak telah disampaikan sebelum ditetapkan sebagai wajib pajak Kriteria Tertentu; dan

c. Jika terjadi keterlambatan penyampaian SPT Masa sesuai dalam huruf b, keterlambatan harus memenuhi ketentuan yaitu:

1) Tidak berturut-turut atau tidak lebih dari 3 (tiga) Masa Pajak,

2) Tidak melampaui batas waktu penyampaian SPT Masa pada Masa Pajak berikutnya.

4. Tidak ada tunggakan pajak atau hutang pajak sesuai ayat 2 huruf b yaitu tidak melewati batas akhir pelunasan, kecuali sudah mendapat ijin penundaan atau pengangsuran.

5. Dalam menyampaikan SPT Tahunan maka harus dilampiri dengan Laporan keuangan yang diaudit oleh akuntan publik atau lembaga pengawasan keuangan pemerintah dan disampaikan selama 3 (tiga) tahun berturut-turut sampai dengan akhir tahun.

Dari pertemuan saya dengan pimpinan PT Continental Panjipratama maka dapat diketahui bahwa tahun buku 2020 pada masa pandemic covid-19 perusahaan mengalami kerugian yang cukup besar. Hal ini terjadi karena PT Continental Panjipratama yang memproduksi tas dan kopor untuk travelling, berlokasi di Jln Kayu Besar III No 8, RT.8/RW 1, Tegal Alur, Kecamatan Kalideres Jakarta Barat 11820 terdampak langsung dengan pandemic yang terjadi. Keputusan pemerintah dalammenetapkan pemberlakuan pembatasan kegiatan masyarakat (PPKM) dan aktivitas lintas Negara di seluruh dunia juga dilakukan pembatasan, hal ini mengakibatkan penjualan produk perusahaan mengalami penurunan yang sangat besar.

Dengan adanya penurunan penjualan, mengakibatkan kerugian yang besar, walaupun sudah dilakukan berbagai upaya penghematan di semua sector yang ada. Dengan lerugian yang 
dialami, maka PT Continental Panjipratama mengalami kelebihan pembayaran pajak yang berasal dari jenis pajak :

\section{Angsuran PPh 25}

2. Pembayaran dan penyetoran $\mathrm{PPh} 22$ Impor

Dari akumulasi pembayaran pajak baik dari PPh 25 maupun PPh 22 impor mendapatkan jumlah kelebihan pembayaran pajak yang cukup besar dan perusahaan memutuskan untuk melakukan Restitusi pajak. Masalah yang dihadapi perusahaan adalah Restitusi pajak harus dilakukan pemeriksaan pajak dan memerlukan waktu maksimal 12 bulan, padahal likuiditas keuangan perusahaan sangat membutuhkan dana segar dengan segera.

Dengan masalah yang dihadapi perusahaan, pihak manajemen meminta bantuan kepada saya dimana tujuan dari ini PKM adalah

1. Mempercepat proses pencairan kelebihan pembayaran pajak ( 2 bulan) melalui permohonan pengembalian pendahuluan pajak pada PT Continental Panjipratama.

2. Membantu proses administrasi permohonan pengembalian pendahuluan pajak supaya dapat diterima dan di proses oleh pihak kantor pelayanan pajak di mana perusahaan terdaftar

3. Memberikan informasi dan persiapan data-data apa saja kepada staff akuntansi dan pajak pada PT Continental Panjipratama.

Dengan keputusan yang diambil pihak manajemen dan koordinasi internal untuk memproses permohonan pengembalian pendahuan pajak diharapkan pihak pemerintah dapat mengabulkan permohonan pengembalian pendahuluan perusahaan. Dengan pencairan kelebihan pembayaran pajak lebih awal, diharapkan dapat membantu cashflow perusahaan yang pada saat ini mengalami penurunan dan kekeringan likuiditas pada masa yang sulit.

Target dari aktivitas penyuluhan dan pendampingan bagi UMKM ini, dapat dijadikan acuan kerja bagi UMKM lainnya khususnya bagi perusahaan-perusahaan yang mengalami kelebihan pembayaran pajak dan mengalami kesulitan cashflow pada masa pandemic. Perusahaanperusahaan yang mengambil keputusan untuk melakukan restitusi pajak mempunyai alternatif mengajukan permohonan pengembalian pendahuluan untuk meningkatkan likuiditas keuangan perusahaan.

Target dari aktivitas penyuluhan bagi Fakultas Ekonomi yaitu untuk dapat dijadikan materi ajar atau referensi tambahan bagi mata kuliah "Perpajakan " terutama bagi Pajak penghasilan tidak final (kredit pajak) PPh 22,23,24, dan angsuran PPh 25 dan pajak pertambahan nilai (PPN) yang mengalami kelebihan bayar, bahwa ada alternatif restitusi pajak yang dipercepat dengan mengajukan permohonan pengembalian pendahuluan dengan waktu kisaran 1-3 bulan, hanya melalui penelitian ketaatan dan kepatuhan dalam melaksanakan kewajiban perpajakan.

Target bagi Mahasiswa diharapkan dapat menjelaskan bagaimana saat mengalami kelebihan pembayaran pajak terdapat alternatif restitusi sebagai berikut:

1. Restitusi normal melalui pemeriksaan sesuai pasal 17B

Saat wajib pajak melakukan restitusi maka DJP melalui Kantor Pelayanan Pajak dimana wajib pajak terdaftar akan melakukan pemeriksaan atas permohonan pengembalian kelebihan pembayaran pajak. Setelah dilakukan pemeriksaan maka DJP harus menerbitkan SKP atau surat ketetapan pajak paling lama 12 (dua belas) bulan sejak surat permohonan diterima secara lengkap. Kecuali permohonan pengembalian kelebihan pembayaran pajak dari Wajib Pajak sesuai Pasal 17C dan Pasal 17D.

2. Restitusi dengan pengembalian pendahuluan (Pasal 17C atau Pasal 17D UU KUP khisis restitusi untuk wajib pajak dengan kriteria tertentu).

Khusus restitusi dengan pengembalian pendahuluan maka DJP akan melakukan penelitian. Setelah dilakukan penelitian akan diterbitkan Surat Keputusan Pengembalian Pendahuluan 
Kelebihan Pajak untuk PPh paling lama 3 (tiga) bulan dan PPN paling lama 1 (satu) bulan sejak permohonan diterima secara lengkap.

Dengan adanya penyuluhan dan pendampingan restitusi dengan pengembalian pendahuluan maka akan terjadi Kerjasama yang nyata antara perusahaan dengan pihak pendidikan sehingga kedua belah pihak mendapatkan manfaat untuk kemajuan bersama

\section{METODE PELAKSANAAN PKM}

Kegiatan PKM dilaksanakan melalui penyuluhan dan pendampingan sesuai dengan keputusan manajemen perusahaan yaitu memproses permohonan pengembalian kelebihan pembayaran pajak yang akan dilakukan perusahaan. Mengajak staf bagian akuntansi dan pajak untuk mempersiapkan dan melakukan review pelaksanaan perpajakan di tahun 2020, memastikan laporan keuangan sudah selesai di internal perusahaan dan laporan keuangan Audit 2020 sudah diterima oleh bagian akuntansi dan pajak. Mempersiapkan pelaporan spt Tahunan 2020 sebagai awal proses permohonan pengembalian kelebihan pembayaran pajak. Selain itu saya melakukan pendampingan berkaitan pola kerja dan analisa seperti pajak final dan pajak tidak final, equalisasi antara spt masa dan tahunan, pengecekan rutin antara data spt sebelum dilaporkan dengan buku besar perusahaan. Untuk mendukung implementasi ini, akan dibuatkan pedoman dasar dan sederhana dalam melakukan review kewajiban perpajakan perusahaan. Aktifitas penyuluhan dan pendampingan akan dilaksanakan secara online via zoom dan perjanjian waktu tertentu untuk datang langsung ke kantor PT Continental Panjipratama

Kegiatan PKM ini bertujuan membantu perusahaan dan diharapkan dapat memberikan manfaat bagi manajemen perusahaan untuk mempersiapkan dan memproses permohonan restitusi sehingga dapat dikabulkan oleh pihak pemerintah. Selain itu membantu dan bekerjasama dengan karyawan perusahaan supaya dapat bekerja dengan lebih terencana dan terkendali, rapi dan konsisten, yang akhirnya tujuan perusahaan dapat tercapai.

\section{Pajak}

Pajak adalah iuran rakyat kepada kas Negara berdasarkan undang - undang (yang dapat dipaksakan) dengan tidak mendapat jasa timbal balik (kontraprestasi) langsung dapat ditunjukkan dan yang digunakan untuk membayar pengeluaran umum” (Mardiasmo, $2016: 1$ ). Adapun ciri-ciri pakak adalah dipakai oleh pemerintah membiayai semua pengeluaran unyuk kepentingan umum dan jikalau ada kelebihan atau surplus akan dipakai untuk membiayai public investment (Resmi 2017:2).

\section{Pengembalian Kelebihan Pembayaran Pajak}

Dalam aktifitas perusahaan memenuhi kewajiban perpajakan tidak menutup kemungkinan terjadi pajak yang telah dibayarkan melebihi dari kewajiban pajak yang seharusnya. Say yerjadi kelebihan pembayaran pajak maka perusahaan dapat mengajukan restitusi sebesar kelebihan pajak yang dibayarkan. Dalam melakukan restitusi pajak untuk jenis PPh melalui SPT Tahunan, sedangkan untuk jenis pajak PPN atau PPnBM melalui SPT Masa PPN. Perusahaan dalam melakukan restitusi pajak dapat diajukan melalui restitusi normal yang memerlukan waktu cukup lama yaitu 12 bulan. Disamping itu perusahaan dapat mengajukan permohonan restitusi pendahuluan dengan proses pengembalian lebih cepat, hanya dilakukan penelitian dilanjutkan dengan pemeriksaan apabila ditemukan data baru. (https://flazztax.com/2020/08/19)

\section{Restitusi}

berkaitan restitusi pajak, PMK No.10/PMK.03/2013 mengatur secara khusus tentang Tata Cara Pengembalian Atas Kelebihan Pembayaran Pajak Yang Seharusnya Tidak Terutang. Dalam 
peraturan, berkenaan adanya kelebihan pembayaran pajak yang seharusnya tidak terutang maka Wajib Pajak dapat mengajukan permohonan pengembalian kepada Direktur Jenderal Pajak (DJP) yaitu:

1. Pembayaran pajak yang seharusnya tidak terutang pajak atau yang bukan merupakan obyek pajak, pembayaran lebih besar daripada pajak terutang, pembayaran atas pembatalan transaksi, pembayaran yang seharusnya tidak terutang pajak

2. Terjadi kesalahan hitung, kesalahan potong, kesalahan pungut atau dibayarkan lebih besar daripada yang seharusnya.

3. Kesalahan pemotongan atau pemungutan pajak penghasilan, pajak pertambahan nilai, pajak penjualan atas barang mewah yang seharusnya tidak dipungut atau dipotong

4. Pembayaran pajak atas barang-barang impor yaitu PPh 22, PPN Impor, pajak penjualan barang mewah impor yang menyebabkan kelebihan pembayaran pajak. Jika hal tersebut terjadi, pihak otoritas pajak melaluibea dan cukai akan melakukan verifikasi dan akan dilakukan pengembalian pajak-pajak diatas saat terbukti tidak terutang pajak.

Dengan terbitnya Peraturan Pemerintah nomor 74 Tahun 2011, dalam rangka menerbitkan surat ketetapan pajak, menerbitkan/menghapus Nomor Pokok Wajib Pajak dan/atau mengukuhkan/mencabut pengukuhan Pengusaha Kena Pajak maka akan dilakukan verifikasi data. Verifikasi adalah serangkaian kegiatan pengujian pemenuhan kewajiban subjektif dan objektif atau penghitungan dan pembayaran pajak, berdasarkan permohonan Wajib Pajak atau berdasarkan data dan informasi perpajakan yang dimiliki atau diperoleh Direktur Jenderal Pajak. Ini merupakan prosedur baru yang diterapkan oleh DJP dimana jika diperlukan tambahan dokumen pendukung seperti bukti pembayaran pajak seperti Surat Setoran Pajak (SSP), SPT Badan jidak terkait PPh maupun SPT Masa PPN atas permohonan pengembalian kelebihan pembayaran pajak yang seharusnya tidak terutang, Jika sesuai dengan ketentuan yang berlaku, maka akan diterbitkan SKPLB (surat ketetapan pajak lebih bayar).

\section{Pemeriksaan Restitusi Pajak}

Saat Wajib Pajak mempunyai kelebihan pembayaran pajak, maka ia mempunyai hak untuk mengajukan permohonan restitusi pajak. Namun, sebelum nya pihak DJP akan melakukan pemeriksaan terhadap permohonan tersebut untuk menguji kebenaran kelebihan pajaknya.berdasarkan pasal 17B UU KUP dimana DJP melakukan pemeriksaan atas permohonan pengembalian kelebihan pembayaran pajak, selain Pasal 17C dan Pasal 17D, harus menerbitkan surat ketetapan pajak paling lama 12 (dua belas) bulan sejak surat permohonan diterima secara lengkap. Pemeriksaan akan dilakukan wajib pajak beresiko rendah yang tidak memenuhi persyaratan, juga yang ditentukan tersebut, dan wajib pajak beresiko rendah yang telah menerima pengembalian kelebihan pajak. Jika hasil pemeriksaan terbukti adanya kekurangan pajak maka akan dikeluarkan Surat Ketetapan Kurang Bayar, dan dikenai sanksi :

1) Sanksi administrasi berupa kenaikan sebesar $100 \%$ (seratus persen) selain pokok pajak SKPKB sesuai pasal 17C ayat (5) atau pasal 17D ayat (5) UU KUP;

2) Sanksi administrasi bunga $2 \%$ (dua persen) per bulan paling lama 24 (dua puluh empat) bulan, selain pokok pajak dalam SKPKB sesuai pasal 13 ayat (2) UU KUP sebagaimana telah diubah UU No 11 Tahun 2020 cipta kerja, diatur dengan Keputusan Menteri Keuangan Republik Indonesia Nomor 57 /Kmk.10/2020 Tentang Tarif Bunga Sebagai Dasar Penghitungan Sanksi Administrasi Berupa Bunga Dan Pemberian Imbalan Bunga.

\section{Pengembalian Pendahuluan Kelebihan Pembayaran Pajak}

Sesuai pasal 17C atau pasal 17D UU KUP maka DJP setelah melakukan penelitian akan menerbitkan Surat Keputusan Pengembalian Pendahuluan Kelebihan Pajak (SKPPKP) atas 782 
restitusi pendahuluan kepada Wajib Pajak Kriteria Tertentu, Wajib Pajak Persyaratan Tertentu, atau Pengusaha Kena Pajak Berisiko Rendah sebagaimana diatur dalam PMK 39/PMK.03/2018.

\section{HASIL DAN PEMBAHASAN}

Dalam pertemuan lanjutan maka dilakukan diskusi dengan pihak manajemen dan staff untuk menentukan materi penyuluhan di PT Continental Panjipratama . Berdasarkan pelaksanaan kewajiban perusahaan dan kondisi pelaksanaan perpajakan perusahaan dengan menyesuaikan persyaratan yang ditetapkan oleh pihak DJP. Bagaimana upaya ini dilakukan supaya keputusan manajemen untuk mengajukan permohonan restitusi pendahuluan bisa dijalankan baik dan berhasil. Melakukan identifikasi dan penelusuran terhadap masalah-masalah yang mungkin akan muncul di bagian akuntansi dan pajak. kemudian dilakukan analisa masalah dan menentukan arah untuk mengatasi masalah yang ada, memperhatikan tingkat pengetahuan para staff

Pelaksanaan penyuluhan dan pendampingan ini dilakukan dengan urutan sebagai berikut:

1. Sesuai waktu yang telah ditentukan, Bersama dengan staff perusahaan dilakukan diskusi untuk mendapatkan keadaan yang sebenarnya baik dari sisi pajak maupun pembukuan di kantor PT Continental Panjipratama yang berlokasi di Jln Kayu Besar III No 8 Tegal Alur, Kalideres, Jakarta Barat..

2. Dilakukan penelaahan persiapan apa saja sesuai dengan persyaratan untuk mengajukan restitusi pendahuluan

3. Menentukan ruang lingkup untuk penyuluhan dan pendampingan termasuk Pembinaan dan penyusunan prosedur di bagian akuntansi dan pajak.

4. Pembuatan dan mendiskusikan materi penyuluhanjar yang akan dibagikan dan bagian terkait.

5. Menentukan hari dan waktu penyuluhan dengan staff perusahaan dan ijin dari manajemen PT Continental Panjipratama.

6. Menggandakan materim dan melaksanakan penyuluhan

7. Melakukan Evaluasi hasil penyuluhan dan memantau perkembangan atau informasi dari DJP hingga penerimaan keputusan dan realisasi pembayaran restitusi le kas perusahaan.

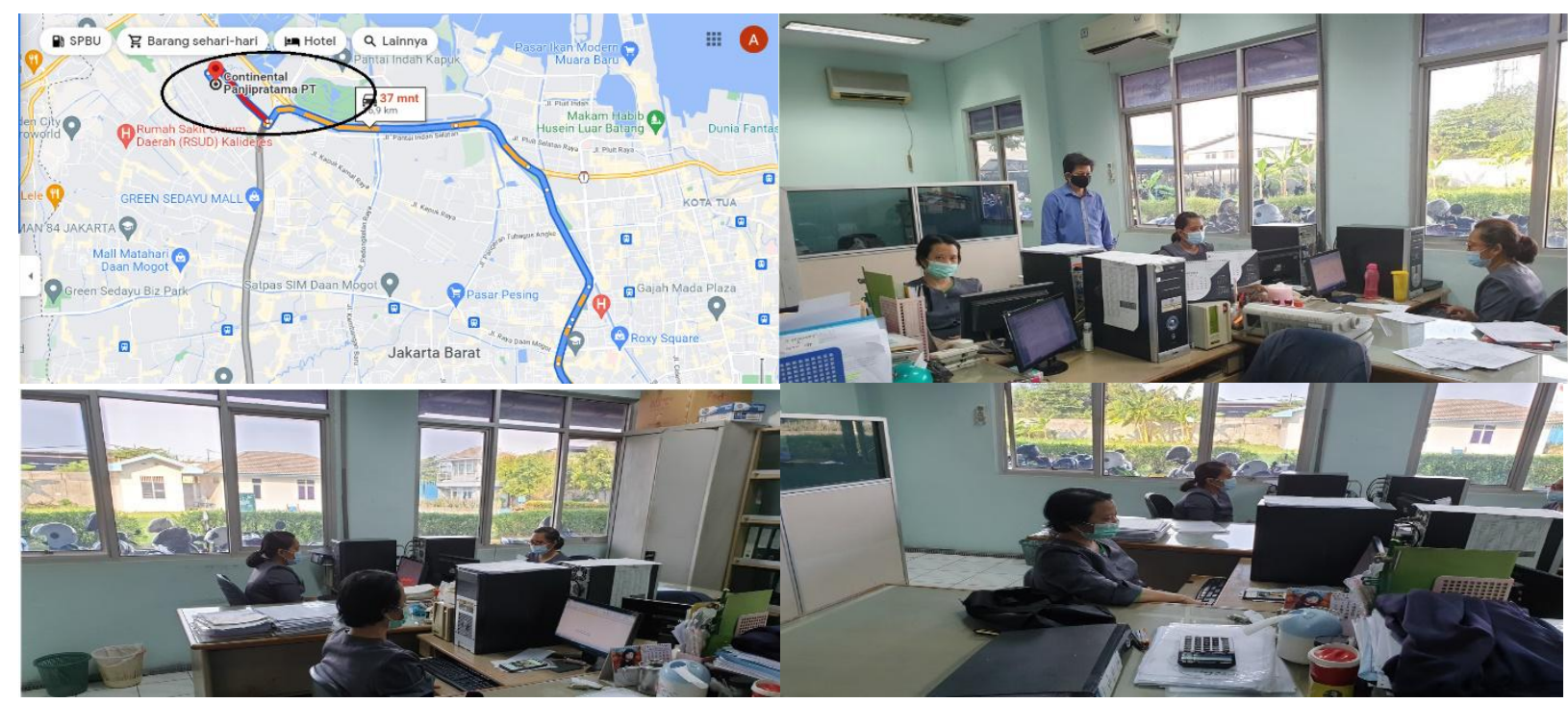

Gambar 1. Dokumentasi kegiatan PKM

(Sumber: Penulis, 2021)

Hasil dari penyuluhan dan pendampingan Pengembalian Pendahuluan Kelebihan Pajak sebagai Alternatif Membantu Cashflow PT Continental Panjipratama pada Masa Pandemi Covid-19 telah selesai dilaksanakan. Hal tersebut memberikan dampak yang sangat positif yaitu : 
1. Dana Segar dari proses permohonan pengembalian kelebihan pembayaran pajak di terima perusahaan, hal ini sangat membantu cashflow perusahaan dalam rangka mempertahankan diri dari dampak pandemi.

2. Berdasarkan Keputusan DJP KEP_00152/SKPPKP/WPJ.07/KP.0203/2021 Tentang Pengembalian Pendahuluan Kelebihan Pembayaran Pajak. Diberikan pengembalian pendahuluan pajak penghasilan tahun 2020 sesuai dengan pasal 17C atau 17D UU KUP No 6 tahun 1983 tentang ketentuan umum dan tata cara perpajakan sebagaimana telah beberapa kali diubah terakhir dengan Undang-Undang Nomor 16 tahun 2009 sebesar Rp xxxxxxxx (terbilang) dengan penghitungan sebagaimana tercantum dalam lampiran yang merupakan bagian tidak terpisahkan dari Keputusan Direktorat Jenderal ini. Ditetapkan 08 Juni 2021

3. Pada tanggal 14 Juni 2021 PT Continental Panjipratama menerima surat dari KPP PMA 1 dengan Nomor : SREK-96/WPJ.07/KP.0203/2021 Tentang Permintaan Rekening Dalam Negeri Perusahaan.

4. Pada tanggal 21 Juni 2021 perusahaan mengirimkan surat Nomor : CPP-DIR007/JI/AB/VI/2021 Tentang Pemberitahuan Rekening Dalam Rangka Pengembalian Kelebihan Pembayaran Pajak Sebagai Res[On Dari surat SREK-96/WPJ.07/KP.0203/2021

5. Pada awal Agustus 2021 dana kelebihan pajak dengan Keputusan DJP No KEP_00152/SKPPKP/WPJ.07/KP.0203/202 diterima secara penuh oleh perusahaan artinya tidak ada potongan dari PPh terutang lainnya.

Dengan keberhasilan permohonan pengembalian pendahuluan kelebihan pembayaran pajak tahun 2020 maka manajemen PT Continental Panjipratama :

1. Lebih memberikan perhatian atas pemenuhan kewajiban perpajakan mulai dari perhitungan, pemotongan, penyetoran dan pelaporan pajak melalui SPT masa maupun SPT Tahunan.

2. Staf bagian akuntansi dan pajak mendapatkan hal-hal yang baru, dimana jika sebelumnya saat ada kelebihan pembayaran pajak dilakukan restitusi pajak dan harus melalui pemeriksaan dengan waktu yang cukup lama dan sangat melelahkan. Dengan mengajukan permohonan pengembalian pendahuluan kelebihan pembayaran pajak, hanya dilakukan penelitian atau verifikasi data yang tentunya jauh lebih ringan dan cepat waktunya (simple dan efisien).

3. Kelebihan pajak oleh pemerintah ditransfer lebih cepat dan tentunya sangat membantu cashflow perusahaan pada masa yang sulit dan tidak menentu seperti saat ini.

4. Dengan meningkatkan kepatuhan dalam membayar pajak, perusahaan mendapatkan manfaat dengan diberikannya fasilitas pengembalian pendahuluan oleh pemerintah.

5. Manajemen dan staff merasakan manfaat atas penyuluhan dan pendampingan dimana hal tersebut meningkatkan likuiditas keuangan perusahaan yang dapat dipakai untuk pembiayaan oprasional PT Continental Panjipratama

\section{KESIMPULAN DAN SARAN}

Pelaksanaan penyuluhan dan pendampingan yang telah dilakukan dirasakan sangat bermanfaat bagi manajemen dan staff bagian akuntansi dan pajak Hal ini dirasakan oleh manajemen PT Continental Panjipratama dengan :

1. Keberhasilan dan cairnya kelebihan pembayaran pajak lebih cepat sehingga meningkatnya likuiditas keuangan perusahaan.

2. Perbaikan Pola kerja bagi internal perusahaan dalam melakukan dan mengendalikan manajemen perpajakan perusahaan.

3. Bagian Akuntansi dan pajak tercipta pola kerja baru dengan kegiatan saling mengontrol dan bagian pajak sendiri senantiasa melakukan pencocokan dan equalisasi pajaknya sebelum dilakukan pelaporan. 
4. Walaupun masih terdapat kekurangan sana-sini di internal perusahaan karena baru tahap penyesuaian. Bagian akuntansi dan pajak mulai tercipta sistem kerja yang baru, yang menunjukkan peningkatan kerapian dan keteraturan kerja

5. Manajemen secara terukur dan pasti dapat mengawasi dan mengontrol aktifitas perusahaan baik yang berasal dari pajak self assessment system maupun withholding system.

6. Masalah-masalah yang terjadi saat proses permohonan pengembalian pendahuluan yaitu :

a. Saat pelaporan SPT tahunan 2020 pada akhir April 2021 melalui E_Filling, pihak yang melakukan penelitian atau verifikasi adalah Account Representative yang menjalankan fungsi pengawasan dan penggalian potensi Wajib Pajak tidak dapat membuka file Audit report 2020 (lampiran SPT Tahunan)

b. Perusahaan sampai melakukan perbaikan pelaporan SPT Tahunan 2020 sebanyak 3 kali karena saat di download laporan audit 2020 tidak bisa dibuka seolah-olah file rusak.

c. Perusahaan sampai mengirimkan file audit report 2020 melalui WA karena di internal perusahaan file tersebut dapat dibuka dengan baik.

d. Saat proses akhir penelitian atau verifikasi AR yang menjalankan proses pengawasan dimutasi ke KPP lain tetapi dengan kesigapan dan kecepatan pihak KPP PMA 1 dapat menyelesaikan dan meloloskan permohonan pengembalian pendahuluan pajak ini.

7. Pihak akademisi secara aktif membantu perusahaan dengan memberikan penyuluhan, pelatihan, pendampingan sesuai dengan bidang ilmu yang dimiliki para dosen secara langsung maupun tidak langsung ikut menjaga dan berperan dalam menjaga roda perekonomian masyarakat.

\section{REFERENSI}

Lempas, B.S , Runtu, T \& Pusung, R.J. (2017). Analisis Sistem Kebijakan Pengembalian Kelebihan Pembayaran Wajib Pajak Orang Pribadi Melalui Restitusi Dan Kompesansi Di Kpp Pratama Manado, Jurnal Riset Akuntansi Going Concern 12(2), 694-702

Mardiasmo. (2016). Perpajakan Edisi Revisi Tahun 2016. Yogyakarta:Penerbit Andi.

Peraturan Menteri Keuangan nomor 10/PMK.03/2013 tentang Tata Cara Pengembalian Atas Kelebihan Pembayaran Pajak Yang Seharusnya Tidak Terutang.

Peraturan Menteri Keuangan Republik Indonesia Nomor 39/Pmk.03/2018 Tentang Tata Cara Pengembalian Pendahuluan Kelebihan Pembayaran Pajak

Resmi, S.( 2017). Perpajakan Teori dan Kasus. Edisi ke 10 Buku 1. Jakarta: Salemba Empat.

Suandy, E. (2011). Hukum Pajak Edisi 5, Jakarta, Salemba Empat.

Undang-Undang Nomor 11 Tahun 2020 tentang Cipta Kerja di Bidang Pajak Penghasilan,Pajak Pertambahan Nilai dan Pajak Penjualan atas Barang Mewah, serta Ketentuan Umum dan Tata Cara Perpajakan

Undang-Undang Republik Indonesia Nomor 28 Tahun 2007 Tentang Perubahan Ketiga Atas Undang-Undang Nomor 6 Tahun 1983 Tentang Ketentuan Umum Dan Tata Cara Perpajakan

Undang-Undang Republik Indonesia Nomor 16 Tahun 2009 Tentang Penetapan Peraturan Pemerintah Pengganti Undang-Undang Nomor 5 Tahun 2008 Tentang Perubahan Keempat Atas Undangundang Nomor 6 Tahun 1983 Tentang Ketentuan Umum Dan Tata Cara Perpajakan Menjadi Undang-Undang

Usman, S. (2017). Restitution and Restitution Examination Managerial Process KPPN Value Added Tax in Manokwari; Jurnal NusambaVol 2, No 1; 2017

Waluyo. (2017). Perpajakan Indonesia; Buku 1. Edisi 12; Penerbit Salemba Empat. Jakarta.

Waluyo. (2019). Perpajakan Indonesia; Buku 2. Edisi 12; Penerbit Salemba Empat. Jakarta. 
Windha, I.S.A. (2021); Pengaruh Restitusi Pajak Pertambahan Nilai Dan Jumlah Pengusaha Kena Pajak Terhadap Penerimaan Pajak Pertambahan Nilai Dengan Sosialisasi Perpajakan Sebagai Variabel Moderasi (Studi Pada Kpp Mulyorejo Surabaya); Jurnal Pabean Vol 3 No 1

https://klikpajak.id/blog/restitusi-pajak-dan-pasal-pasal-yang-mengaturnya/ https://flazztax.com/2019/11/27/sudahkah-anda-mengetahui-apa-itu-restitusipajak/\#: :text=Restitusi\%20pajak\%20ialah\%20permohonan\%20pengembalian, sebelumnya\%20t elah\%20dibayarkan\%20Wajib\%20Pajak. https://news.ddtc.co.id/cara-mengajukan-restitusi-dipercepat-pph-badan-24288 https://flazztax.com/2020/08/19/tahukah-anda-tentang-restitusi-pajak-atau-pengembaliankelebihan-bayar-pajak/ 